This article was downloaded by: [Australian National University]

On: 04 November 2012, At: 15:27

Publisher: Routledge

Informa Ltd Registered in England and Wales Registered Number: 1072954 Registered

office: Mortimer House, 37-41 Mortimer Street, London W1T 3J H, UK

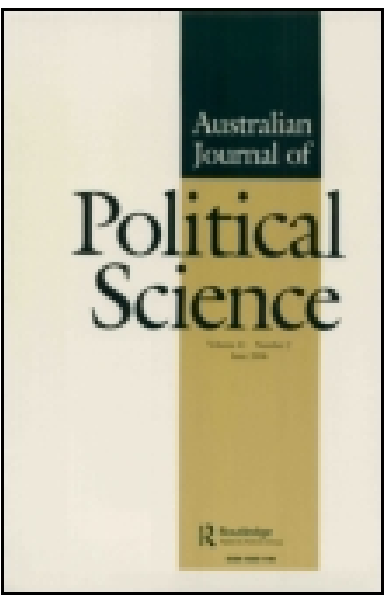

\author{
Australian J ournal of Political Science \\ Publication details, including instructions for authors and \\ subscription information: \\ http:// www.tandfonline.com/loi/ cajp20
}

\title{
Change and Continuity in the Ideology of Australian Prime Ministers: The Governor-General's Speeches, 1946-2010
}

Keith Dowding ${ }^{a}$, Nicholas Faulkner ${ }^{b}$, Andrew Hindmoor ${ }^{c} \&$ Aaron Martin ${ }^{\mathrm{d}}$

${ }^{a}$ Australian National University

${ }^{b}$ Monash University

${ }^{c}$ University of Queensland

d University of Melbourne

Version of record first published: 11 Sep 2012.

To cite this article: Keith Dowding, Nicholas Faulkner, Andrew Hindmoor \& Aaron Martin (2012): Change and Continuity in the Ideology of Australian Prime Ministers: The Governor-General's Speeches, 1946-2010, Australian J ournal of Political Science, 47:3, 455-472

To link to this article: http:// dx. doi.org/ 10.1080/10361146.2012.703999

\section{PLEASE SCROLL DOWN FOR ARTICLE}

Full terms and conditions of use: http://www.tandfonline.com/page/terms-andconditions

This article may be used for research, teaching, and private study purposes. Any substantial or systematic reproduction, redistribution, reselling, loan, sub-licensing, systematic supply, or distribution in any form to anyone is expressly forbidden.

The publisher does not give any warranty express or implied or make any representation that the contents will be complete or accurate or up to date. The accuracy of any instructions, formulae, and drug doses should be independently verified with primary sources. The publisher shall not be liable for any loss, actions, claims, proceedings, demand, or costs or damages whatsoever or howsoever caused arising directly or indirectly in connection with or arising out of the use of this material. 


\title{
Change and Continuity in the Ideology of Australian Prime Ministers: The Governor- General's Speeches, 1946-2010
}

\author{
KeITH Dowding \\ Australian National University \\ Nicholas FAulKNeR \\ Monash University \\ ANDREW HindMOOR \\ University of Queensland \\ AARON MARTIN \\ University of Melbourne
}

\begin{abstract}
In Australian politics, narratives have developed around the ideological lineage of prime ministers from the same party so that, for example, Howard is often compared to Menzies and Hawke to Whitlam. In this article we examine the extent to which the ideology (left-right) of prime ministers from the same party has changed over time. We analyse the contents of speeches the Governor-General delivered at the opening of parliament between 1946 and 2010. We validate a number of narratives around the ideological lineage of prime ministers in relation to their party predecessors, and invalidate others, by analysing the speeches using the Comparative Manifestos Project coding scheme. This article also argues that parties do matter and shows how the addition of coding for ideology can complement the Policy Agendas Project method.
\end{abstract}

Keywords: Australian politics; ideology; policy agendas

\footnotetext{
Keith Dowding is Professor of Political Science in the School of Politics and International Relations and Research Director, College of Arts and Social Science, at the Australian National University. Nicholas Faulkner is a doctoral student at Monash University and was employed through the University of Queensland Research Scholarship Program. Andrew Hindmoor is Associate Professor of Politics in the School of Political Science and International Studies at the University of Queensland. Aaron Martin is Lecturer in Political Science in the School of Social and Political Sciences at the University of Melbourne.
} 


\section{Introduction}

Seeing parties as occupying particular spatial positions provides an efficient way of conveying information. ${ }^{9}$ Whether parties are moving leftwards or rightwards might be disputed, but such labels serve as common reference points for parties and leaders. The spatial metaphor offers a kind of political Esperanto, a shared political language to describe political events and policies in different countries and at different times (Hindmoor 2004). The spatial metaphor is longstanding, first used during the French Revolution based on where deputies sat in the National Assembly debating chamber (Laponce 1981, 48-51). The ideological dimension is constructed from issue-dimensions but other orthogonal dimensions such as the environment or, in Europe, over further political and economic integration, might also affect a government's position along the leftright spectrum (Hinich and Munger 1994). Indeed, some prophesy the decline of left and right as poles of political orientation (Giddens 1984).

Within contemporary political discourse, the language of left and right remains salient (Bobbio 1996; Mair 2007). Left and right are terms routinely used for inter-party and intra-party comparison. Inter-party comparisons are drawn when one party is described as being more left- or right-wing than another. Intra-party comparisons are drawn when a party or leader is described as being situated to the left or right of predecessors or successors. Our interest is in this second type of comparison. For example, Prime Minister John Howard presented himself as a political heir of Robert Menzies, but critics suggest he moved the Liberal Party well to the right of Menzies' centrism (Rundle 2001). Similarly, Jaensch (1989) argued that Bob Hawke and Paul Keating 'hijacked' the Labor Party, moving it rightwards.

In the first part of this article, we scrutinise common propositions found in the literature on intra-party, left-right spatial positioning. We then use the Comparative Manifestos Project (CMP) coding scheme to examine these debates. We formally estimate the left-right spatial location of post-war prime ministers (PMs) when, at the start of a new parliament, they outline their legislative program, policy preferences, and public expenditure and taxation priorities, through the Governor-General's speech.

Estimating a party's spatial position through coding documents, expert surveys or roll-call voting is commonplace in political science. Indeed, a mini-industry has emerged testing the reliability and consistency of the available coding methods (for a review, see Volkens 2007). Such quantitative coding is not superior to the kind of qualitative evidence we survey here. We do not use our quantitative results to test the veracity of that evidence. Rather, we use it to cast new light on existing debates to see where different judgements lie. After all, the quantitative evidence using CMP is itself based on subjective and qualitative insights.

\section{Change and Continuity in the Ideology of the PMs}

We outline where the most influential literature places prime ministers ideologically, between 1946 and 2010. Our summary is not comprehensive

\footnotetext{
${ }^{1}$ The research in this paper is supported by the ARC Discovery grant DP110102622 'Policy Agendas in the Australian Commonwealth Government'.
} 
but represents informed opinion highlighting areas of disagreement. This account of the ideological placement of PMs is not straightforward because authors rarely spell out explicitly where they place each of the leaders on a leftright scale. Nevertheless, we can infer spatial positioning where authors make clear, albeit indirect, statements about the left-right positions of the prime ministers.

\section{Labor Party PMS}

The first Governor-General's (GG) speech we analyse is Ben Chifley's in 1946. The next Labor PM we analyse is Gough Whitlam. How similar are they on the left-right dimension? Murray $(1999,148)$ argued that Labor under Chifley 'believed that many industries should be in government ownership and that governments should plan and control others' as a way of creating a more equal society (see also Macintyre 2004, 200). McMullin (2000, 268) argued that Chifley 'genuinely and effortlessly symbolised the ideals of the labour movement more than any other leader in the ALP's entire history'. Accordingly, '[a] spirit of socialism pervaded Ben Chifley's Labor Party' (Murray 1999, 148).

Like Chifley, Whitlam pursued a distinctly left-wing policy agenda promising 'to deliver equality of opportunity to all Australians through a greater role for the federal government in education, health, welfare, justice, the environment, transport and human rights as applied to Aborigines, voters and women' (Kelly 2000b, 35; see also Lloyd 2000, 327). Manne (1999, 182, 188) depicted the Whitlam ministry as radical, energetic and optimistic, representing a 'symbol of hope for a new generation of the cultural left'. However, Whitlam waged struggles with the party's doctrinaire left (Manne 1999, 180) and pursued some policies that could be seen as right-wing. For example, his tariff cuts put Australia at the forefront of market reform and at odds with the party's old tradition (Lloyd 2000, 327). Furthermore, Manne (1999, 182) argued that Labor's previous socialist platform had been diluted by the time Whitlam entered politics. While both leaders pursued a strong left-wing agenda, Whitlam is seen as a party moderniser who, on some issues, broke with party tradition. Therefore, we should expect some discontinuity between Chifley and Whitlam, with Whitlam coded to the right of Chifley, although not as much as later Labor PMs.

After Whitlam, one of the main lines of dispute concerns how far subsequent Labor leaders abandoned Australian Labor Party (ALP) tradition. Jaensch (1989) wrote of the Hawke-Keating 'hijack' and Kelly $(2008,14)$ argued that Hawke represents a new generation of Labor leader. Kelly $(2008,20)$ claimed the new values Hawke and Keating imposed upon the ALP 'were a belief in economic competition. A faith in market forces, a commitment to the internationalisation of the Australian economy, reform sanctioned by a consensus process, and government in collaboration with the ACTU [Australian Council of Trade Unions] leadership'. Kelly (2008, 23) argued further that Hawke decided the government's 'priority must become economic growth', accepting free market orthodoxy, and he realised he would need the support of corporate and financial interests. Hawke pursued closer ties with the business and financial community (Blewett 2000, 389; see also Kelly 2008, 19), in stark contrast to Whitlam who believed in enduring prosperity (Manne 1999, 
183). Yet the Hawke government also pursued more progressive policies such as elevating environmental issues in 1987 (Blewett 2000, 401; Kelly 2008, 526). Nonetheless, Kelly $(2000$ b, 25) argued that the Hawke and Keating governments will be remembered foremost for economic reform.

The Hawke government's economic approach was a sharp departure from Labor tradition, outflanking the Liberals (Kelly 2000b, 249). The leadership did not shy away from the reputation of economic modernisers - first as treasurer and then as PM, Keating promoted Labor's economic reform credentials. Keating argued that: 'We are the first generation of post-war politicians and economic managers to foster a genuinely open Australian economy' (cited in Macintyre 2004, 247). Therefore we would expect Hawke to be coded far to the right of Whitlam and Chifley.

Reviewing the literature on Keating as PM presents a slightly different picture. Much more than Hawke, Keating's agenda is often portrayed as dominated by cultural issues, especially after the 1993 election when Keating became occupied with his 'big picture' politics (Macintyre 2004, 260). Kelly (2008, xxix) argued that Keating's development of a cultural agenda to accompany his economic one was the new feature of politics in the 1990s. This involved 'Aboriginal reconciliation, a republic, the fostering of multicultural nationalism, deepening ties with the Asia-Pacific and the cultivation of a more confident community' (Kelly 2008, xxix; see also Day 2000; Macintyre 2004, 259). This cultural agenda led the public to believe that Keating had moved too far to the left between 1993 and 1996 (Kelly 2011, 93). These cultural issues were very different from those Chifley championed, but they were a partial return to Labor Party tradition. Thus we expect Keating to be coded to the left of Hawke, but to the right of Whitlam and Chifley.

In contrast to the reformist audacity of the Whitlam and Hawke-Keating years, Kevin Rudd and Julia Gillard are depicted as modern, pragmatic, polldriven leaders, replacing conviction leaders such as Hawke and Keating (see Megalogenis 2010; Ramsey 2011). Rudd (2006) describes himself as a social democrat with an ideology in strong contrast to that of the Liberal Party (Kelly 2011, 269). Gillard (2010) invoked Chifley as a model for her government. Yet many have been unimpressed by the perceived shallowness of their leadership. Megalogenis $(2010,61)$ argued that 'Rudd proved to be too conservative for the nation he led' (see also Marr 2010). John Kerin, a former Labor parliamentarian, accuses Gillard of having no philosophy and standing for nothing (see Ramsey 2011, xxvi). Ramsey (2011, xvii) also depicted Gillard as a 'manufactured politician'. Commentators see Rudd and Gillard as poll-driven politicians lacking the firm political principles or the focus needed to carve out a distinctive policy agenda.

The literature suggests there has been great variation in the ideological stance of Labor PMs. Whitlam and Chifley are seen as pursuing distinctly left-wing agendas, while the Hawke years in particular are regarded as a departure from Labor Party tradition. Rudd and Gillard, on the other hand, are depicted as modern pragmatic leaders lacking the reformist agenda of their predecessors. Nonetheless, the extent to which different leaders continued or broke with Labor Party tradition is not entirely clear in these accounts. Our coding of the GG speeches can track changes in terms of how PMs set ideological agendas for their governments. 


\section{Liberal Party PMs}

Similar disputes concern the ideological lineage of Liberal leaders. ${ }^{2}$ Perhaps the largest involves Malcolm Fraser and John Howard, stretching back to Howard's term as treasurer under Fraser. As treasurer, Howard tried to convince Fraser to be more aggressive on financial deregulation (Errington and van Onselen 2008, 89). Howard is among those who depict Fraser as weak for not advancing financial deregulation (Kelly 2000a, 361). Such criticisms broadly see Fraser as a status quo leader without the political tenacity to pursue the larger reforms of later governments.

Kelly (2000a, 357) viewed Fraser as 'a regulator, a protectionist and a champion of state intervention'. He argues that Fraser was suspicious of financial power and was 'really a disciplinarian upholding the Australian tradition against the rising tide of pro-market reformers that broke through with Bob Hawke's 1983 victory'. In this sense Fraser is seen to be following the Menzies tradition and to be very different from Howard (Kelly 2000a, 357; 2008, 37). Similarly, Errington and van Onselen $(2008,58)$ claimed that 'Fraser believed that individual freedom was under threat as much from big business as from big government. In this respect, he was more a Menziean than Howard has been as Liberal leader' (see also Kelly 2000a, 357). This ideological divide became more evident recently when Fraser publically criticised Howard for being too right-wing (Kelly 2008, 228). While Howard was PM, Fraser criticised the Liberals for becoming the party of 'economic rationalists' who 'believe that the role of government should be minimised, that the marketplace should be the supreme arbiter of activity' (cited in Kelly 2011, 84).

This raises an interesting inconsistency in analysis of the ideological positions of Liberal PMs. Observers such as Kelly (2000a; 2008) regard Fraser as a follower of the Menzies tradition, in contrast to Howard. Howard, however, presents himself as heir to that same tradition (Errington and van Onselen 2008, 401; Rundle 2001) and casts Menzies as a hero (Errington and van Onselen 2008, 58).

How much have Menzies and Howard in common? Errington and van Onselen argued that Howard overturned many of Menzies' policies. They rebutted suggestions that Howard was Menzies' redux (2008, 18, 409). Rundle (2001) highlighted the differences between Howard and Menzies. Howard 'argues that in attempting to fuse free-market economic liberalism with social conservatism he carries on the Menzies tradition', but Rundle (2001, 11) countered that Howard 'has been the disposer of it'. Thus views differ over how much Menzies, Fraser and Howard have in common. We address this issue through analysis of GG speeches during their terms in office.

Implicit in this discussion is the question of how right-wing John Howard really was. Some see him as extremely right-wing, while others see him as more moderate. Manne $(2008,11)$ argued that 'Howard's period of leadership is best understood as the attempted neoliberal/neoconservative reconstruction of the Liberal Party tradition'. Rundle $(2001,12)$ also argued that Howard implemented the 'greatest reconfiguration of conservative politics since the

${ }^{2}$ Our discussion concentrates on Robert Menzies, Malcolm Fraser and John Howard because John Gorton, William McMahon and Harold Holt had only short terms in office. 
founding of the Liberal Party in 1944'. Others, however, depict Howard as less ideological and more pragmatic. Errington and van Onselen (2008, xiv) claimed that Howard 'learned the value of pragmatism' (see also Grattan 2000). Brett (2005) also argued that Howard was more moderate and mainstream than many critics allow. Similarly, Kelly $(2011,632)$ countered the view of Howard as a neoliberal, arguing that he did not shrink the size of government, dramatically cut taxes or scrap Medicare. Kelly (2011) considered Howard's time as PM to be a continuation of Hawke-Keating government reformism, suggesting that Howard won in 1996 on a platform not dissimilar to Keating's (Kelly 2000b, 77; 2011; pace Manne 2009). Therefore, while we would expect Howard to be coded to the right of Menzies and Fraser, how far to the right remains in question.

\section{The Formal Coding of Spatial Position}

These debates generate considerable insights but they are limited by the absence of transparent, let alone agreed, criteria of comparison. Dispute over the ideological placement of prime ministers might be due to different conceptions of left and right, which issues matter or how to assess those issues. For this reason, political scientists construct estimates of spatial position using agreed coding criteria. The resulting methods and techniques differ by:

(1) the dimension coded - material can be coded for left-right position, progressive or conservative politics, or any dimension of political conflict;

(2) the subject of the coding exercise - whether content analysis of written documents, roll-call votes, expert surveys or self-placement questionnaires;

(3) the method of coding - whether manually by trained research assistants or by computer software.

We employ the CMP method promoted by the Social Science Research Centre Berlin since 1989. This manually codes for left-right position on the basis of a content analysis of written documents, usually party manifestos. Researchers manually code written texts at the quasi-sentence level. A quasisentence is an expression of a single policy idea or issue and, as the name suggests, need not be a complete sentence.

The CMP method uses a system encompassing seven broad policy domains and 56 categories. ${ }^{3}$ The results are then scaled to create standardised scores allowing documents of different lengths to be compared. The standard CMP measure - the Rile scale - measures the total number of 'right-wing' statements minus the number of 'left-wing' statements as a proportion of the total number of statements within a document. More formally, where $R$ is the total number of 'right' quasi-sentences, $L$ the total number of 'left' quasi-sentences, and $N$ the total number of quasi-sentences:

$$
\theta^{(s)}=\frac{R-L}{N} \times 100
$$

\footnotetext{
${ }^{3}$ See the Manifesto Project Database at: <http://manifestoproject.wzb.eu $>$.
} 
The Rile scale ranges from 100 (for a party devoting its program exclusively to right-wing issues) to -100 (for a party devoting its program exclusively to left-wing issues). Of the 56 categories, only 26 are classified under CMP as left- or right-wing. The left pole comprises positions of intervention in market systems, extensions of the welfare state, peace, disarmament and internationalisation. The right pole covers the free market economy, limitations of the welfare state, traditional morality, law and order, military strength, national autonomy and national culture (Budge et al. 2001, 22).

Spatial position is determined not simply by the relative balance of leftand right-wing statements but by the number of left-wing versus right-wing statements relative to all statements. This has important implications for the consistency of coding (see below). Lowe et al. (2011) discussed the merits of the Rile scale and two other measures: the relative proportional difference scale and the logit scale. We use the Rile scale to calculate position. No significant consequences follow from this choice. The Pearson Correlation between the Rile scale and the proportional difference and logit scales for our results was .991 and .989 respectively. The Krippendorff alpha measure of agreement between all three scales was .879 (Hayes and Krippendorff 2007).

The CMP method of coding has, until recently, enjoyed a "near monopoly status in the field' (Laver and Garry 2000, 620). It has been used to code more than three thousand election manifestos issued by more than 650 parties in over 50 countries (Lowe et al. 2011, 124). There are recognised limits to the approach. It cannot take account of a party's internal disagreements (Ray 1999). It measures willingness to change position rather than actual position (Pelizzo 2003). It also risks exaggerating spatial differences between parties because manifestos often downplay areas of common agreement (Budge 1987).

Nonetheless, meta-analysis shows that CMP coding consistently generates reliable results in two important senses. First, results are internally reliable, demonstrating a high level of inter-coding agreement, the result of a rigorous coding manual and training procedure (Volkens 2007, 109). Put simply, when confronted with the same text, different coders code in a similar way. Second, results derived from the CMP method are externally reliable in the sense that they are generally consistent with results derived from other content coding techniques and expert surveys. Volkens, Bara and Budge $(2009,241)$ reported that manifesto left-right and expert left-right scales correlate in the order of $0.85-0.95$.

The great advantage of the CMP method for our purposes is that it uses a fixed and transparent definition of what constitutes 'left' and 'right', making possible meaningful comparisons of spatial position over time. The clear objection to CMP is that what constitutes left and right changes over time, and that flux affects judgements about the ideological position of prime ministers. However, the CMP method is preferable to other coding techniques precisely because it is better equipped to deal with this problem.

When estimating left-right position, the CMP method focuses on attitudes towards a fixed set of issues. This list does not seek to include a complete account of what it may mean for a party to be left- or right-wing at any 
particular time. Rather, it seeks to capture an enduring sense of what continues to define left and right, linking these judgements across time (Volkens, Bara and Budge 2009, 240). The lexicon of Australian politics has changed such that politicians now eschew specific words such as 'nationalisation' or 'planning'. This poses problems for coding techniques that analyse variations in the way certain words are used. The CMP method, by contrast, requires only that there is consistency over time in the way in which left and right are defined in terms of underlying attitudes towards fundamental economic and social choices. The external reliability of CMP coding suggests that there is such consistency over time.

The CMP method takes account of the changing circumstances of political debate by using trained researchers to manually code text. In the case of general attitudes, for example, towards government regulation, the specific policy issues under consideration change over time. Because the CMP method relies on manual coding by trained researchers, new issues can be recognised and coded as new manifestations of longstanding areas of disagreement. Evidence coded using the CMP method can be aggregated in a quantitative form. Coding itself, however, is a qualitative exercise (Krippendorff 2004, 16; Volkens 2007, 117).

Evidence on spatial position derived from the CMP method is not superior to, or a replacement for, evidence derived from informal judgement. Debate over whether content analysis or historical surveys better capture the 'real' positions of political parties is misdirected, since the notion of a 'real' position is elusive, even metaphysical (Laver and Garry 2000, 620). On the contrary, the two approaches are complementary. Our data constitute an additional source of evidence on spatial trajectories, but our tolerance on this point ought to cut both ways. In our experience, those sceptical of the value of formal approaches tend to dismiss coded data either as confirming what they already know and so adding nothing of value or, if it shows something unexpected, as obviously wrong. This means their views cannot be challenged - a convenience not often remarked on. We think conventional wisdom should not be treated as sacrosanct. In the case at hand, moreover, there is not always a conventional wisdom.

The CMP method has usually been applied to manifestos. This choice has proven controversial. An established secondary literature discusses its strengths and weaknesses, and the extent to which it generates consistent results (Dinas and Germenis 2009; Heman 2007; McDonald, Silva and Myunghee 2007; Volkens 2007). Critics argue that manifestos are strategic documents written to appease and entice voters and journalists. Hence they should not be viewed as true indicators of a party's underlying policy preferences (see Benoit, Laver and Mikhaylov 2009, 499; Budge 2001).

In the Australian context, parties have not traditionally issued a single manifesto document but instead relied on speeches and program documents reflecting the context of particular campaign issues. There is no reason why the CMP method need only be applied to manifestos. We have coded the content of 26 speeches delivered by Governors-General at the opening of parliament between November 1946 and September 2010. GG speeches are delivered by the Governors-General but written by prime ministers in consultation with senior 
colleagues. We take the speeches to be an expression of the spatial positions of prime ministers. 4

The GG speech is a particularly suitable text for coding because its format has remained largely unchanged. Benoit, Laver and Mikhaylov (2009) demonstrated that the reliability of CMP results is affected by, among other things, the length of the document. Thirty per cent of the manifestos coded through the CMP contain fewer than 100 quasi-sentences. In contrast, the GG speeches constitute substantial pieces of text, averaging 3,500 words. Furthermore, unlike manifestos, the length of the speeches has not varied significantly over time.

The GG speeches we analyse here are delivered in the aftermath of an election. They not only tend to avoid partisan attacks but also provide what the government thinks it can achieve in the post-election environment, rather than a 'wish list' of policy promises. Nonetheless, the GG speech cannot tell us anything about intra-party dissent. Neither can it tell us anything about the significance of particular policy positions, other than the proportional attention devoted to that issue in a speech. A PM might choose to downplay a given issue in the speech in order to minimise controversy. Finally, the GG speech is only a statement of political intention, not what a government actually achieves. In short, the GG speech is a political event that can be used by prime ministers to establish their position. We should be wary of assuming that the GG speech (or, for that matter, any other document) fully reflects spatial position.

\section{Results}

We calculate the left-right position of $26 \mathrm{GG}$ speeches delivered between November 1946 and September 2010 using the standard policy classifications, and coding and scaling methods, of the CMP. We exclude from our analysis nine speeches delivered between elections to coincide with the appointment of a new Senate or a royal visit, and the 186-word holding speech delivered in November 1969. In addition to the speeches examined in Dowding et al. (2010) we analyse Gillard's September 2010 speech. Coding reliability was assessed against a sample text provided by the CMP, and a second researcher then blindcoded one-third of the speeches.

The reliability of CMP coding has previously been assessed using correlation coefficients to determine the extent to which a coder's ratings are associated with those of either a 'gold standard' reference text (the usual method) or those of another coder. Mikhaylov, Laver and Benoit (2010) showed that this will generate misleading results if, for example, coders' results consistently differ from each other. They argue that the level of agreement is the key reliability measure, that is, the extent to which one variable equals the other. Krippendorff's alpha is a standard content analysis measure of agreement (Hayes and Krippendorff 2007; Mikhaylov, Laver and Benoit 2010, 14).

\footnotetext{
${ }^{4}$ The Governor-General has no influence over the policy content of the speech. Occasionally a GG may suggest a modest rewording of phrases used within the speech but this is the limit of their influence (Dowding et al. 2010, 537-38; and personal correspondence with Peter Boyce, University of Tasmania).
} 
Krippendorff's alpha values range from 0 (perfect disagreement) to 1 (perfect agreement). Krippendorff $(2004,241)$ suggested that variables with reliabilities greater than $\alpha=0.800$ are reliable. Our overall Rile (that is, left-right) ratings show a very high level of correlation $(r=0.932)$, and a high level of inter-coder agreement $(\alpha=.840)$. The percentage of quasi-sentences placed into each individual category also shows a high level of inter-coder agreement $(r=0.8)$. Comparing our results with existing CMP findings for Australia also shows a high level of association $(r=0.802)$ between the Rile score measures of preelection speeches and the post-election GG speeches. One difference is that Liberal pre-election speeches are consistently coded as being more right-wing than Liberal GG speeches. ${ }^{5}$

Our results are shown in Figures 1-3. Figure 1 shows, in chronological order, the left-right Rile measure for each of the 26 post-election speeches. Right-wing speeches have a value of greater than zero and left-wing speeches a value lower than zero.

Figure 2 takes the same information and shows, along a sliding scale, the leftright position of each prime minister in terms of the mean average of their postelection speeches. The number of speeches written by each PM varies. Menzies had seven speeches, while Rudd, Chifley, Harold Holt, Gillard, John Gorton and Keating had only one each.

Finally, Figure 3 measures the spatial (left-right) difference between each speech and the speech immediately preceding it, a difference calculated according to the formula: ${ }^{6}$

$$
\mathrm{DRS}_{\mathrm{t}}=\left|\mathrm{RS}_{\mathrm{t}}-\mathrm{RS}_{\mathrm{t}}-{ }_{1}\right|
$$

Speeches that are ideologically further apart are on the left-hand side of the figure. The shading in this figure distinguishes between speeches where there is a change in both the party in office and (therefore) the PM; speeches where there is a change in PM but no change in governing party; and those where there is no change in either the governing party or the PM.

\section{Analysis}

Labor Party PMS

Figures 1 and 2 show that Whitlam is to the left of Chifley, by a considerable margin in 1973. This result is somewhat surprising given the 'spirit of socialism' pervading the Labor Party while Chifley was PM (Murray 1999, 148). It can be explained not by the socialism of Whitlam's speech but rather by Whitlam's rush to put new cultural 'left-wing' issues on the agenda. The extent of social progress is readily forgotten - for example, people are often shocked when they uncover the casual racism of past left-wing or socially liberal writers or politicians. That said, Chifley and Whitlam are found here to be to the left of all other Labor leaders and that is broadly consistent with the literature cited above.

\footnotetext{
${ }^{5}$ Further details are available upon request.

${ }^{6}$ Where $\mathrm{RS}_{\mathrm{t}}$ and $\mathrm{RS}_{\mathrm{t}-1}$ are the Rile scores at time $t$ and time $t_{-1}$.
} 


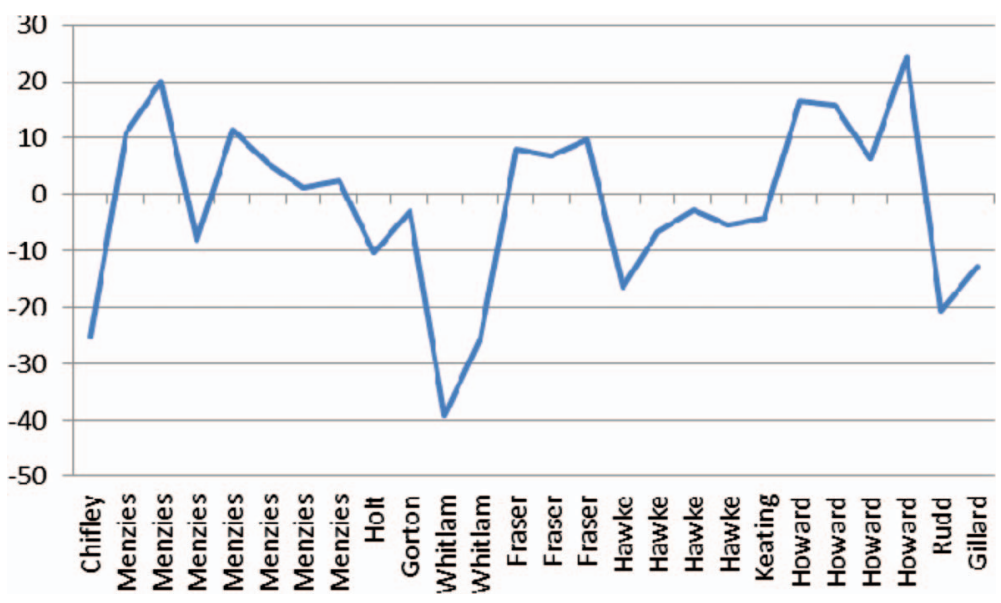

Figure 1. Rile Scores (26 Speeches, November 1946-September 2010).

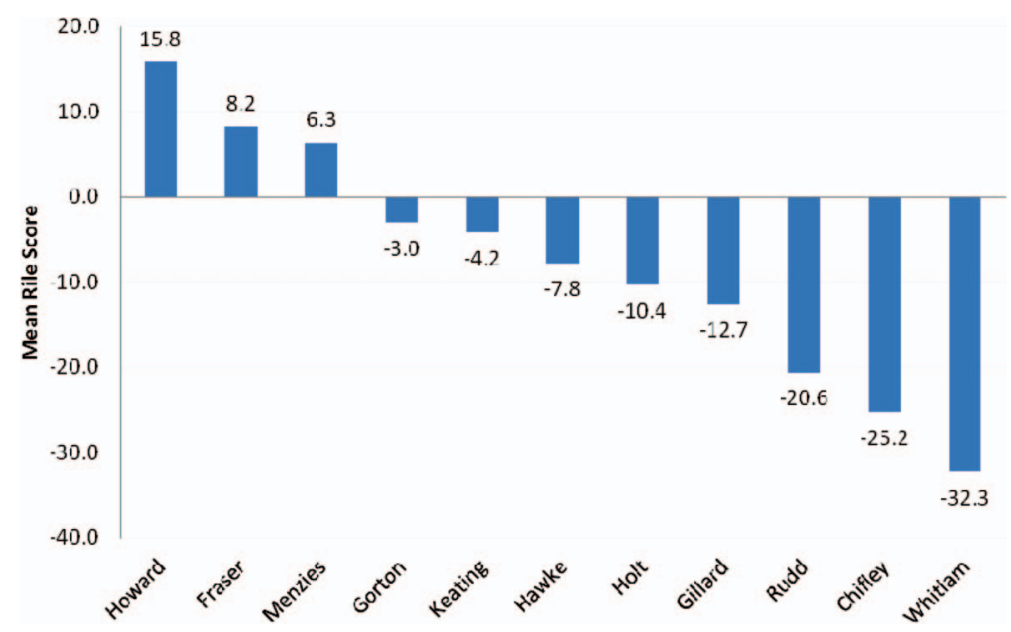

Figure 2. Mean Rile Scores by Prime Minister throughout Time in Office (26 Speeches, November 1946-September 2010).

It is reasonable to expect that Hawke would be coded to the right of previous Labor leaders, given his government's economic reform agenda. Indeed, Hawke's mean Rile score (Figure 2) is to the right of all other Labor leaders except Keating. Again this is broadly consistent with the literature. However, Keating's spatial position is surprising. Keating's mean Rile score, contrary to the expectations outlined above, is to the right of Hawke, and Keating is the least left-wing Labor PM. Claims that Keating moved too far to the left between 1993 and 1996 (Kelly 2011, 93) are not supported here. This is consistent with Dowding et al. (2010) who found that there was little difference between Hawke's 1990 and Keating's 1993 GG speech in terms of their policy 


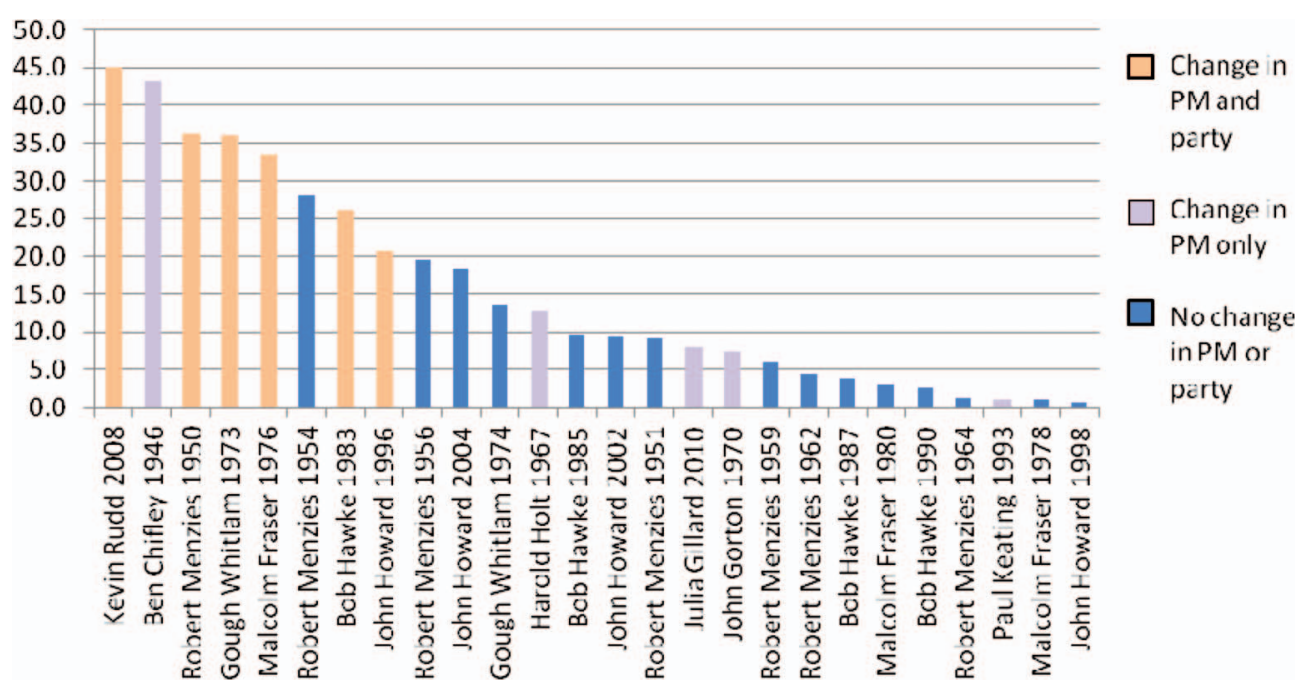

Figure 3. Changes in Rile Score from Previous GG Speech (26 Speeches, November 1946September 2010).

agenda. Indeed, Keating's 1993 GG speech is one of the most ideologically continuous (Figure 3).

What about the new generation of Labor leaders? Political analysts such as Megalogenis (2010) and Ramsey (2011) depict Rudd and Gillard as modern, pragmatic, poll-driven leaders without a distinct ideology. In contrast, Rudd argues that his government had a distinct ideology far to the left of the Liberal Party (Kelly 2011, 269). Gillard (2010) cites Curtin and Chifley as her inspiration. Our analysis finds that Rudd's 2008 speech constitutes the greatest post-war ideological punctuation (Figure 3), and that only the Chifley and Whitlam speeches are to the left of it (Figure 2). Whether Rudd lived up to the radicalism of his 2008 speech during his limited time in office, however, is a different matter.

The transition from Rudd to Gillard is also included in our findings. Our data show that in her 2010 GG speech, Gillard moved significantly to the right of Rudd. This reflects the extraordinary nature of the transition, as well as Gillard's pragmatism and the moderation required in the circumstances of the election that led to her becoming prime minister. Nevertheless, the data show that Rudd and Gillard are further to the left than would be expected on the basis of the literature above. In this case, the characterisations given by the leaders themselves are more accurate.

Our analysis of Labor Party PMs suggests there is a great deal of ideological change over time. The Chifley and Whitlam governments are found to be distinctly left-wing, while Hawke and Keating are found to have remoulded Labor Party tradition. Is this Jaensch's 'hijack'? We cannot answer this question with certainty. However, consistent with the literature, it is shown that Hawke and Keating moved the party far to the right. More surprisingly, Rudd and Gillard moved the party leftwards. Perhaps the rhetoric of the modern era 
is more at odds with action than it has been in the past, or perhaps contemporary commentators are simply voicing their own disappointment. At any rate, Rudd and Gillard express a stronger left-wing agenda in their GG speeches than is commonly recognised.

\section{Liberal Party PMS}

Do Liberal prime ministers display a greater ideological continuity than their Labor counterparts? Figure 1 shows that Menzies shifted his ideological position over time. In terms of his mean Rile score (Figure 2), however, he is broadly a centrist leader. This classification is consistent with Menzies' own depiction of his party as representing the 'middle of the road' (Manne 1999, 129). However, Menzies' time in office has been seen as a continuation rather than a decisive break from the previous Labor government (see Hancock 1999, 120; Kelly 2011, 3; Martin 1999). This view is not supported here: Menzies is found to be far to the right of Chifley.

A deep ideological dispute persists over the relative positions of Fraser and Howard. Given Fraser's trenchant criticisms of Howard, Fraser should be far to the left of Howard and this is borne out in Figure 2. Fraser's mean Rile score is 8.2 compared with Howard's 15.8. Nonetheless, Fraser is still to the right of Menzies, Gorton and Holt. Therefore prior to Howard, Fraser moved the party rightwards. Whereas Fraser is only slightly to the right of Menzies, however, Howard is significantly to the right of them both. Howard liked to depict himself as an heir to Menzies, but he was very different from his hero. Our data support Manne (2008) and not Kelly (2011). The data suggest that Howard was less pragmatic than some argue and support the view that Fraser had more in common with Menzies than Howard (Kelly 2000a, 357). In this regard, Howard (leaving Holt aside) represents the largest break from Liberal Party tradition.

\section{Ideology and the Policy Agenda}

In observing the effect of leaders on the ideological agenda of their party, we also observe their effect on the ideological landscape overall. Thus we build on the work done by Dowding et al. (2010) on policy agendas over time. One of their key findings relates to the impact of the 1972 election. Dowding et al. $(2010,546)$ argued that Whitlam may only have been prime minister for three years but that 'in terms of the expectations engendered... the Whitlam government engineered a decisive change in the policy agenda that still has reverberations today'. Our data show Whitlam to be to the left of any other post-war prime minister (see Figure 2) and that his first GG speech in February 1973 was one of the more significant post-war ideological punctuations (see Figure 3).

We note two aspects revealed by the ideology coding. Prior to Whitlam's election, the Coalition's speeches had moved to the left, being coded as marginally 'left-wing' under Holt especially, as well as under Gorton. This suggests that there was a perceived shift in attitudes prior to Whitlam's election. Second, and more important, while Dowding et al. (2010) found that in terms of the agenda, Whitlam provided a turning point, we find that in ideological terms Whitlam's period in office constitutes a clear punctuation rather than a turning point. Fraser and Howard may have focused broadly upon the same set 
of policy issues as Whitlam, but in ideological terms they shifted the country to the right (see Figure 1). Whitlam changed the policy agenda but he did not permanently change the ideological landscape. If anything, there was a rightwing reaction to Whitlam.

That Whitlam shifted the policy agenda but not the ideological landscape suggests a more general finding about the relationship between ideological change (found in this article) and agenda change (as outlined by Dowding et al. 2010). Dowding et al. (2010, 541-44) reported a secular increase in the attention devoted to, in particular, health, education and welfare issues by successive governments. What difference has this made to the ideological landscape? We might expect it to have made a discernible difference if the issues that have risen in prominence are more left-wing than those they have eclipsed. There is a general consensus between the parties on the need for significant taxpayer support for health and education. As politicians have come increasingly to talk about health and education, has this led them to make more statements classified as left-wing by the CMP? The simple answer is no.

We found little statistical evidence of any association between the emphasis given to issues within the Policy Agendas classification and spatial position. The one exception is macroeconomics. Speeches paying relatively more attention to macroeconomics are coded as more right-wing $(r=0.39)$. There is, however, no statistically significant association between the relative emphases placed on health, education, civil rights or social welfare issues and ideological position. It is known that voters have enduring preferences between the parties over particular issues. ${ }^{7}$ There is no apparent relationship, however, between agenda change and ideological change. Secular changes in the policy agenda have coincided with trendless fluctuation in ideological position (see Figure 1).

It is instructive to consider the reasons why Hawke and Keating appear so far to the right of the other Labor PMs. A key determinant of left-right position on the CMP scale is economic policy. An emphasis upon free enterprise, economic incentives, economic orthodoxy and free trade are coded as right-wing. An emphasis upon regulation, economic planning, protectionism and nationalisation, and economic control are coded as left-wing (Budge et al. 2001, 22). Hawke and Keating pursued an economic agenda of deregulation, privatisation and tariff reduction. These policies have not been undone, and thus far they have shifted the spectrum enduringly to the right. These issues are not currently on the agenda, however, and Rudd and Gillard's ideological positions are measured by the stance they take on issues on the agenda.

The CMP and Policy Agendas Project (PAP) ${ }^{8}$ methods facilitate comparative analysis: we can measure not only whether Hawke was to the right or left of Whitlam, but whether, when and to what extent political parties across the

\footnotetext{
${ }^{7}$ Newspoll shows that voters favoured Labor over the Liberals as the party 'best equipped to handle health and Medicare' in 56 of 58 polls taken between 1990 and July 2010 (the exceptions being 1991 and 1992). For education, Newspoll shows that Labor held a lead in 30 out of 31 polls since 1991, with one tied in 2002. But in 42 out of 49 polls between 1989 and 2008, the Liberals were seen as the party best equipped to handle taxation. See $<$ http://www.newspoll.com.au/ index.pl?action $=$ adv_search $>$.

${ }^{8}$ The Policy Agendas Project examines the stability of policy agendas over time. The original project of Baumgartner and Jones (1993) inspired a similar exercise, the Comparative Agendas Project (CAP), in countries around the world. Australia is now a part of the CAP.
} 
world moved to the right in the 1980s. Moreover, the CMP can show whether parties moved to the right because of changes in their economic policies or changes in their attitudes toward other issues, such as law and order. In this case, the CMP method finds that Hawke and Keating were to the right of Whitlam, but that Australia did not move nearly as far to the right in the 1980s as the United Kingdom or the United States (for comparative estimates, see Budge et al. 2001, 24-6). These findings need to be treated carefully and in their proper context. They do not necessarily contradict supporters of Hawke and Keating who argue that, in the Australian context, deregulation and tariff reform were politically progressive policies that challenged the profits and prerogatives of big business.

\section{Do Parties Make a Difference?}

Our argument about the political significance of Whitlam, Hawke and Rudd leads us directly to our final discovery over the enduring significance of political parties and electoral change in structuring the content of post-war politics. Dowding et al. (2010, 539) contrasted theoretical literature that emphasises policy inheritance with literature that presents elections as harbingers of policy change. In terms of agenda change, they found that for four out of eight speeches, the most significant changes in the content of the policy agenda occurred following a change in the governing party (Dowding et al. 2010). Yet they also found evidence of significant agenda change in the absence of any alteration in governing party or its leader, in the speeches of Menzies (1959), Gorton (1970) and Hawke (1990 and 1998). Our findings here are less ambiguous.

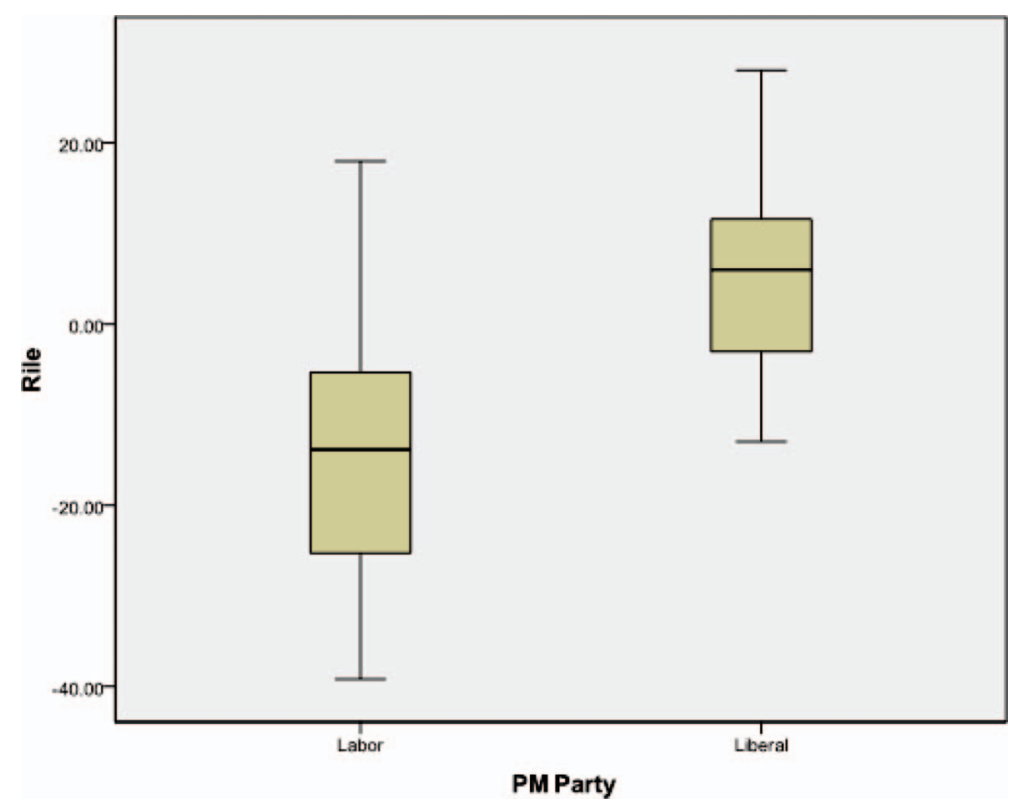

Figure 4. Boxplot of Labor and Liberal Rile Scores. 
Figure 3 indicates that five of the six largest post-war ideological punctuations occur immediately following a change in the governing party (the exception is Chifley's 1946 speech and this was preceded by a wartime speech). Conversely, eight of the nine speeches with the smallest changes in ideological position relate to a PM who had also written the previous GG speech (the exception is Keating, 1993).

The enduring significance of political parties is further underlined in Figure 4. Using the same set of data, this figure plots the ideological range adopted by Labor and the Liberals, showing the minimum, the lower quartile, the median, the upper quartile and the maximum Rile score for each party. As we might expect, the Labor mean $(M=-14.83)$ is substantially to the left of the Liberal mean $(M=7.38)$, and highly statistically significant $(t \quad(23)=-5.08$, $p<.001)$. Moreover, the Labor mean is significantly to the left of zero. In addition, Labor PMs are ideologically spread more than Liberal PMs, consistent with the analysis above.

\section{Conclusion}

We have ideologically coded the GG speeches using the CMP method, allowing us to test in a systematic manner the extent to which PMs within each party differ ideologically from each other. We find that Chifley's and Whitlam's ideological positions accord with accounts found in the literature. We find that Whitlam is to the left of other Labor leaders. However, while Dowding et al. (2010) found that Whitlam permanently transformed the policy agenda, our analysis shows that he did not fundamentally shift the ideological spectrum quite the reverse. There was a right-wing reaction to his time in office. Ideologically, Whitlam represents a punctuation and not a turning point. We also find Hawke and Keating to be the least leftward of all Labor leaders, surprisingly in Keating's case given his cultural agenda between 1993 and 1996. Hawke and Keating clearly moved the party to the right and their economic shift has been permanent - it was a turning point. We find that Rudd and Gillard moved the party leftwards, contrary to depictions of them as pragmatic and less ideological than their predecessors.

Among Liberal PMs we find a clear ideological break between Menzies, Holt and Gorton on the one hand, and Howard on the other. Howard is the most right-wing of all Liberal PMs and very different, in ideological terms, from his hero Menzies.

Finally, we have shown the enduring influence of political parties and electoral change. We find that the greatest ideological punctuations occur when a new party comes to power. Our analysis has made further progress in charting the policy agenda in Australia by exploring the spatial dimension of the GG speeches.

\section{References}

Baumgartner, F.R. and Jones, B.D. 1993. Agendas and Instability in American Politics. Chicago: Chicago University Press.

Benoit, K., Laver, M. and Mikhaylov, S. 2009. 'Treating Words as Data with Error: Uncertainty in Text Statements of Policy Positions'. American Journal of Political Science 53: 495-513. 
Blewett, N. 2000. 'Robert Hawke'. In: M. Grattan, ed. Australian Prime Ministers. Frenchs Forest, NSW: New Holland.

Bobbio, N. 1996. Left and Right: The Significance of a Political Distinction. Cambridge: Polity. Brett, J. 2005. 'Relaxed and Comfortable: The Liberal Party's Australia'. Quarterly Essay 19, August.

Budge, I. 1987. 'The Internal Analysis of Election Programs'. In: I. Budge, D. Robertson and D. Hearl, eds. Ideology, Strategy and Party Change: Spatial Analysis of Post-War Election Programs in 25 Democracies. Cambridge: Cambridge University Press.

Budge, I. 2001. 'Validating Party Policy Placements'. British Journal of Political Science 31: 210 23.

Budge, I., Klingemann, H., Volkens, A., Bara, J. and Tannenbaum, E. 2001. Mapping Policy Preferences: Estimates for Parties, Electors and Governments, 1945-88. Oxford: Oxford University Press.

Day, D. 2000. 'Paul John Keating'. In: M. Grattan, ed. Australian Prime Ministers. Frenchs Forest, NSW: New Holland.

Dinas, E. and Germenis, K. 2009. 'Measuring Parties' Ideological Positions with Manifesto Data: A Critical Evaluation of the Competing Methods'. Party Politics 16: 427-50.

Dowding, K., Hindmoor, A., Iles, R. and John, P. 2010. 'Policy Agendas in Australian Politics: The Governor-General's Speeches, 1945-2008'. Australian Journal of Political Science 45: 533-57.

Errington, W. and van Onselen, P. 2008. John Winston Howard: The Definitive Biography. Melbourne: Melbourne University Press.

Giddens, A. 1984. Beyond Left and Right: The Future of Radical Politics. Cambridge: Cambridge University Press.

Gillard, Julia. 2010. 'Light on the hill address'. Bathurst, 18 September. URL: $<$ http:// www.alp.org.au/federal-government/news/speech-julia-gillard, - light-on-the-hill-address/ $>$. Consulted 1 June 2011.

Grattan, M. 2000. 'John Winston Howard'. In: M. Grattan, ed. Australian Prime Ministers. Frenchs Forest, NSW: New Holland.

Hancock, R. 1999. 'The Rise of the Liberal Party'. In: R. Manne, ed. The Australian Century: Political Struggle in the Building of a Nation. Melbourne: Text Publishing.

Hayes, A. and Krippendorff, K. 2007. "Answering the Call for a Standard Reliability Measure for Coding Data'. Communication Methods and Measures 1: 77-89.

Heman, H. 2007. 'Experts and Manifestos: Different Sources - Same Results for Comparative Research?' Electoral Studies 26: 76-89.

Hindmoor, A. 2004. New Labour at the Centre: Constructing Political Space. Oxford: Oxford University Press.

Hinich, M. and Munger, M. 1994. Ideology and the Theory of Political Choice. Ann Arbor: University of Michigan Press.

Jaensch, D. 1989. The Hawke-Keating Hijack: The ALP in Transition. Crows Nest, NSW: Allen \& Unwin.

Kelly, P. 2000a. 'Malcolm Fraser'. In: M. Grattan, ed. Australian Prime Ministers. Frenchs Forest, NSW: New Holland.

Kelly, P. 2000b. Paradise Divided: The Changes, the Challenges, the Choices for Australia. St Leonards, NSW: Allen \& Unwin.

Kelly, P. 2008. The End of Certainty. St Leonards, NSW: Allen \& Unwin.

Kelly, P. 2011. The March of Patriots: The Struggle for Modern Australia. Melbourne: Melbourne University Press.

Krippendorff, K. 2004. Content Analysis: An Introduction to its Methodology. Thousand Oaks, CA: Sage.

Laponce, J. 1981. Left and Right: The Topography of Political Perceptions. Toronto: University of Toronto Press.

Laver, M. and Garry, J. 2000. 'Estimating Policy Positions from Political Texts'. American Journal of Political Science 44: 619-34.

Lloyd, C. 2000. 'Gough Whitlam'. In: M. Grattan, ed. Australian Prime Ministers. Frenchs Forest, NSW: New Holland.

Lowe, W., Benoit, K., Mikhaylov, S. and Laver, M. 2011. 'Scaling Policy Preferences from Coded Political Text'. Legislative Studies Quarterly 26: 123-55.

Macintyre, S. 2004. A Concise History of Australia. Cambridge: Cambridge University Press.

Mair, P. 2007. 'Left-Right Orientations'. In: R. Dalton and H. Klingemann, eds. The Oxford Handbook of Political Behaviour. Oxford: Oxford University Press.

Manne, R. 1999. 'The Whitlam Revolution'. In: R. Manne, ed. The Australian Century: Political Struggle in the Building of a Nation. Melbourne: Text Publishing.

Manne, R. 2008. 'What Went Wrong?' In: P. van Onselen, ed. The Liberals and Power: The Road Ahead. Carlton: Melbourne University Press.

Manne, R. 2009. 'The Insider'. The Monthly, October, 22-8. 
Marr, D. 2010. Power Trip: The Political Journey of Kevin Rudd. Melbourne: Black Inc.

Martin, A. 1999. Robert Menzies: A Life. Carlton, Vic.: Melbourne University Press.

McDonald, M., Silva, M. and Myunghee, K. 2007. 'Cross-Temporal and Cross-National Comparisons of Party Left-Right Positions'. Electoral Studies 26: 62-75.

McMullin, R. 2000. 'Ben Chifley'. In: M. Grattan, ed. Australian Prime Ministers. Frenchs Forest, NSW: New Holland.

Megalogenis, G. 2010. Trivial Pursuit: Leadership and the End of the Reform Era. Melbourne: Black Inc.

Mikhaylov, S., Laver, M. and Benoit, K. 2010. Coder Reliability and Misclassification in the Human Coding of Party Manifestos. URL: < http://as.nyu.edu/docs/IO/2791/CMP_reliability.pdf $>$. Consulted 2 January 2010.

Murray, R. 1999. 'The Split'. In: R. Manne, ed. The Australian Century: Political Struggle in the Building of a Nation. Melbourne: Text Publishing.

Pelizzo, R. 2003. 'Party Positions or Party Direction? An Analysis of Party Manifesto Data'. West European Politics 26: 67-89.

Ramsey, A. 2011. The Way They Were: 25 Years that Made Australia. Sydney: University of New South Wales Press.

Ray, L. 1999. 'Measuring Party Positions on European Integration: Results from an Expert Survey'. European Journal of Political Research 36: 283-306.

Rudd, K. 2006. 'Faith in Politics'. The Monthly, October, 22-30.

Rundle, G. 2001. 'The Opportunist: John Howard and the Triumph of Reaction'. Quarterly Essay 3, October.

Volkens, A. 2007. 'Strengths and Weaknesses of Approaches to Measuring Policy Positions of Parties'. Electoral Studies 26: 108-20.

Volkens, A., Bara, J. and Budge, I. 2009. 'Data Quality in Content Analysis: The Case of the Comparative Manifestos Project'. Historical Social Research 34: 234-51. 